\title{
Factors influencing particulate lipid production in the East Atlantic Ocean
}

\author{
B. Gašparovic ${ }^{\mathrm{a}, *}$, S. Frka ${ }^{\mathrm{a}}$, B.P. Koch ${ }^{\mathrm{b}, \mathrm{c}}$, Z.Y. Zhu ${ }^{\mathrm{d}}$, A. Bracher ${ }^{\mathrm{b}}$, O.J. Lechtenfeld $^{\mathrm{b}, 1}$, \\ S.B. Neogi ${ }^{\text {e,f }}$, R.J. Lara ${ }^{\mathrm{g}}$, G. Kattner ${ }^{\mathrm{b}}$ \\ a Division for Marine and Environmental Research, Ruđer Bošković Institute, POB 180, HR-10002 Zagreb, Croatia \\ ${ }^{\mathrm{b}}$ Alfred-Wegener-Institut Helmholtz-Zentrum für Polar- und Meeresforschung, Am Handelshafen 12, 27570 Bremerhaven, Germany

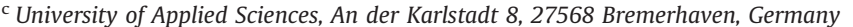 \\ d State Key Laboratory of Estuarine and Coastal Research, East China Normal University, No. 3663 North Zhongshan Road, Shanghai 200062, PR China \\ e Graduate School of Life and Environmental Sciences, Osaka Prefecture University, Sakai, Osaka 599-8531, Japan \\ f International Centre for Diarrhoeal Disease Research, Bangladesh, 68 Shaheed Tajuddin Ahmed Sarani, Mohakhali, Dhaka 1212, Bangladesh \\ ${ }^{\mathrm{g}}$ Leibniz Centre for Tropical Marine Ecology GmbH, Fahrenheitstr. 6, 28359 Bremen, Germany
}

\section{A R T I C L E I N F O}

\section{Article history:}

Received 16 September 2013

Received in revised form

2 April 2014

Accepted 7 April 2014

Available online 21 April 2014

\section{Keywords:}

Lipids

POC

Phytoplankton size classes

Heterotrophic prokaryotes

Eastern Atlantic Ocean

\begin{abstract}
A B S T R A C T
Extensive analyses of particulate lipids and lipid classes were conducted to gain insight into lipid production and related factors along the biogeochemical provinces of the Eastern Atlantic Ocean. Data are supported by particulate organic carbon (POC), chlorophyll $a(\mathrm{Chl} a)$, phaeopigments, Chl $a$ concentrations and carbon content of eukaryotic micro-, nano- and picophytoplankton, including cell abundances for the latter two and for cyanobacteria and prokaryotic heterotrophs. We focused on the productive ocean surface ( $2 \mathrm{~m}$ depth and deep Chl $a$ maximum (DCM)). Samples from the deep ocean provided information about the relative reactivity and preservation potential of particular lipid classes. Surface and DCM particulate lipid concentrations $\left(3.5-29.4 \mu \mathrm{g} \mathrm{L}^{-1}\right)$ were higher than in samples from deep waters (3.2-9.3 $\mu \mathrm{g} \mathrm{L}^{-1}$ ) where an increased contribution to the POC pool was observed. The highest lipid concentrations were measured in high latitude temperate waters and in the North Atlantic Tropical Gyral Province $\left(13-25^{\circ} \mathrm{N}\right)$. Factors responsible for the enhanced lipid synthesis in the eastern Atlantic appeared to be phytoplankton size (micro, nano, pico) and the low nutrient status with microphytoplankton having the most expressed influence in the surface and eukaryotic nano- and picophytoplankton in the DCM layer. Higher lipid to $\mathrm{Chl} a$ ratios suggest enhanced lipid biosynthesis in the nutrient poorer regions. The various lipid classes pointed to possible mechanisms of phytoplankton adaptation to the nutritional conditions. Thus, it is likely that adaptation comprises the replacement of membrane phospholipids by non-phosphorus containing glycolipids under low phosphorus conditions. The qualitative and quantitative lipid compositions revealed that phospholipids were the most degradable lipids, and their occurrence decreased with increasing depth. In contrast, wax esters, possibly originating from zooplankton, survived downward transport probably due to the fast sinking rate of particles (fecal pellets). The important contribution of glycolipids in deep waters reflected their relatively stable nature and degradation resistance. A lipid-based proxy for the lipid degradative state (Lipolysis Index) suggests that many lipid classes were quite resistant to degradation even in the deep ocean.
\end{abstract}

(c) 2014 Elsevier Ltd. All rights reserved.

\section{Introduction}

Investigations of quantity, characterization, and distribution of marine organic matter are important to understand the role of

\footnotetext{
* Corresponding author. Tel.: +38514561 148; fax: +38514680242.

E-mail address: gaspar@irb.hr (B. Gašparović).

${ }^{1}$ Present address: University of South Carolina, Department of Biological Sciences, Marine Science Program, Columbia, SC 29208, USA.
}

marine sources and sinks of organic carbon. Marine organic matter is predominantly of autochthonous origin, produced by the phytoplankton community and heterotrophic organisms. Phytoplankton accounts for about 95\% of the primary production in the ocean and about half of all primary production on Earth (Field et al., 1998). In general, open ocean primary production is mainly driven by picophytoplankton and nanophytoplankton. Microphytoplankton biomass shows a larger variability than smaller phytoplankton on seasonal and interannual time scales (Uitz et al., 2010). 
Phytoplankton blooms cover a wide range of scales from small, sporadic blooms stimulated by event scale processes to the basin scale spring blooms covering the North Atlantic (Ducklow and Harris, 1993).

Lipids are important components of photosynthetically produced particulate organic carbon (POC) (Yoshimura et al., 2009). Polar lipids, in particular phosphatidylglycerols, diphosphatidylglycerols, phosphatidylethanolamines and phosphatidylcholines, are biomembrane structure components and reflect the organic matter associated with living organisms (Derieux et al., 1998). The neutral lipids, triacylglycerols and wax esters, represent metabolic reserves. Triacylglycerols are the main phytoplankton storage lipids whereas marine zooplankton also store energy as dense wax esters (Lee et al., 2006) that are usually also found in their fecal pellets (Wakeham et al., 1984). Glycolipids (GL) are the most common non-phosphorous polar lipids in the biosphere (Härtel et al., 2000). In algae, as in higher plants and cyanobacteria, GL are predominantly located in the photosynthetic membranes (thylakoids) (Guschina and Harwood, 2009) where they are the most abundant type of lipids. Diacylglycerols, monoacylglycerols and free fatty acids are breakdown products and characterize lipid degradation (Parrish, 1988; Goutx et al., 2003). Fatty alcohols originate mainly from degradation of zooplankton wax esters. The "Lipolysis Index" (LI) has been defined by Goutx et al. (2003) and indicates the degree of lipid degradation. The quantity and quality of lipids depend on the life cycle stage of the primary producers and environmental factors (Zhukova and Aizdaicher, 2001). The characterization of marine lipids on a molecular level enables their use as efficient geochemical markers for the identification of sources, carbon cycling and reactivity of organic matter in the ocean.

Oceans are systems of physically-driven, biologically controlled chemical cycles which regulate the planetary climate over large spatial and temporal scales (Ducklow, 2003). Longhurst (2007) produced an ecological scheme dividing the oceans into a system of regions, named biogeographic provinces, which are regions or water masses with similar physical (e.g. sea surface temperature, mixed-layer depth, and bathymetry) and biological (e.g. chlorophyll a concentration, photosynthetic parameters, and biomass vertical profile) characteristics. The most fundamental distinction among provinces in the Atlantic Ocean is between the coastal and open ocean domains (Sathyendranath et al., 1995). However, there is little information about the quality and quantity of lipids in different oceanic provinces.

In this work, we aimed to examine lipids under the range of various biological and chemical conditions that exist over a long north-south transect through the East Atlantic to gain insight into: (i) their biological origin, (ii) influence of inorganic nutrient availability on lipid production and composition and (iii) distribution of the lipids within the water column. We quantified lipid classes in the particulate matter from the surface productive layers and the deep ocean waters and compared these data with the plankton community structure. To understand the influence of environmental conditions we performed sampling at stations encompassing a wide range of trophic states.

\section{Material and methods}

\subsection{Study area and sample collection}

Water sampling was conducted from 31 October to 3 December, 2008, during the R/V Polarstern cruise ANT-XXV/1. The sampling locations, extending from $49^{\circ} \mathrm{N}$ to $26^{\circ} \mathrm{S}$, are shown in Fig. $1 \mathrm{a}$. Samples were collected continuously at the surface (ca. $2 \mathrm{~m}$ ), at various depths of the deep Chl $a$ maximum (DCM; 25-105 m), and in the deep ocean (805-5563 m; Fig. 1b). The different symbols in the figures refer to the different biogeochemical provinces introduced by Longhurst (2007): the Northeast Atlantic Shelves Province (1st: NECS; $4-50^{\circ} \mathrm{N}$; Sta. 4 and 5; down triangles); the North Atlantic Drift (2nd: NADR; 44-48 N; Sta. 9-22; squares); the North Atlantic Subtropical Gyre-East (3rd: NASE; $26-44^{\circ} \mathrm{N}$; Sta. 24-63; up triangles); the North Atlantic Tropical Gyral Province, touching the Canary Current Coastal Province (4th: NATR; $13-25^{\circ}$; Sta. 65-105; stars); the Western Tropical Atlantic Province (5th: WTRA; $11-12^{\circ} \mathrm{N}$; Sta. 107-109; hexagons); the Eastern Tropical Atlantic Province (6th: ETRA; $11^{\circ} \mathrm{N}-8^{\circ} \mathrm{S}$; Sta. $119-162$; rhombs); the South Atlantic Gyral Province (7th: SATL; 11-22 ${ }^{\circ}$; Sta. 167-195; circles); the Benguela Current Coastal Province (8th: BENG; 23-31 ${ }^{\circ}$; Sta. 200-214; right triangles).

Surface water samples were collected with the so-called 'Fish' sampler (Sarthou et al., 2003), which had a fish-like floating body with Teflon tubing and pumping. It was fixed alongside the ship, providing a continuous flow of water from $\sim 2 \mathrm{~m}$ water depth. Samples from various depths of DCM and deep waters were taken using 12 L Niskin bottles mounted on a CTD-rosette.

\subsection{Eukaryotic plankton cell abundance and pigment analysis}

Cell abundances of eukaryotic nano- and picophytoplankton and cyanobacteria (including Synechococcus and Prochlorococcus) were assessed using flow cytometry. Full descriptions of the method for the flow-cytometric enumeration of autotrophic cells are provided in Taylor et al. (2013). The data have been published in PANGAEA (http://dx.doi.org/10.1594/PANGAEA.823283).

The composition of phytoplankton pigments which are soluble in organic solvents was analyzed by high performance liquid chromatography (HPLC) following the method by Barlow et al. (1997), slightly modified by Hoffmann et al. (2006), and adapted to our instruments as described in Taylor et al. (2011). The data have been published in PANGAEA (http://dx.doi.org/10.1594/PANGAEA. 819070).

The relative proportions of eukaryotic micro- $(20-200 \mu \mathrm{m})$, nano- $(2-20 \mu \mathrm{m})$ and picophytoplankton $(<2 \mu \mathrm{m})$ were estimated from the concentrations of 7 diagnostic pigments after Uitz et al. (2006). Briefly

$$
\begin{aligned}
& \% \text { Pico }=100 \times(0.86 \text { Zea }) / \mathrm{DPw} \\
& \% \text { Nano }=100 \times(1.2719 \mathrm{HF}+1.01 \mathrm{TChl} b+0.3519 \mathrm{BF}+0.6 \text { Allo }) / \mathrm{DPw} \\
& \% \text { Micro }=100 \times(1.41 \text { Fuco }+1.41 \text { Peri }) / \mathrm{DPw},
\end{aligned}
$$

where $\mathrm{DPw}=0.86$ Zea $+1.01 \quad \mathrm{TChl} b+1.27 \quad 19 \mathrm{HF}+0.35 \quad 19 \mathrm{BF}+0.6$ Allo+1.41 Fuco+1.41 Peri; Zeaxanthin (Zea), total Chlorophyll-b (TChlb), 190-hexanoyloxyfucoxanthin (19HF), 190-butanoyloxyfucoxanthin (19BF), Alloxanthin (Allo), Fucoxanthin (Fuco), Peridinin (Peri). An additional correction for Fuco, accounting for the contribution by haptophytes (identified by the marker pigment 19HF) was applied as detailed in Hirata et al. (2011). The percentage of Chl $a$ in individual classes is calculated from their calculated percentage and the total Chl $a$.

The carbon content of phytoplankton was calculated from the Chl $a$ after Pérez et al. (2006) using the carbon to Chl $a$ (C/Chl $a$ ) ratios of 77 for eukaryotic picophytoplankton and of 186 for eukaryotic nano- and microphytoplankton for surface samples, and for the DCM samples the $\mathrm{C} / \mathrm{Chl} a$ ratios were 17 for eukaryotic pico- and 58 for nano- and microphytoplankton.

\subsection{Prokaryotic heterotroph abundance}

The number of total prokaryotic heterotrophs including bacteria and archaea were estimated by a culture independent microscopic 
a

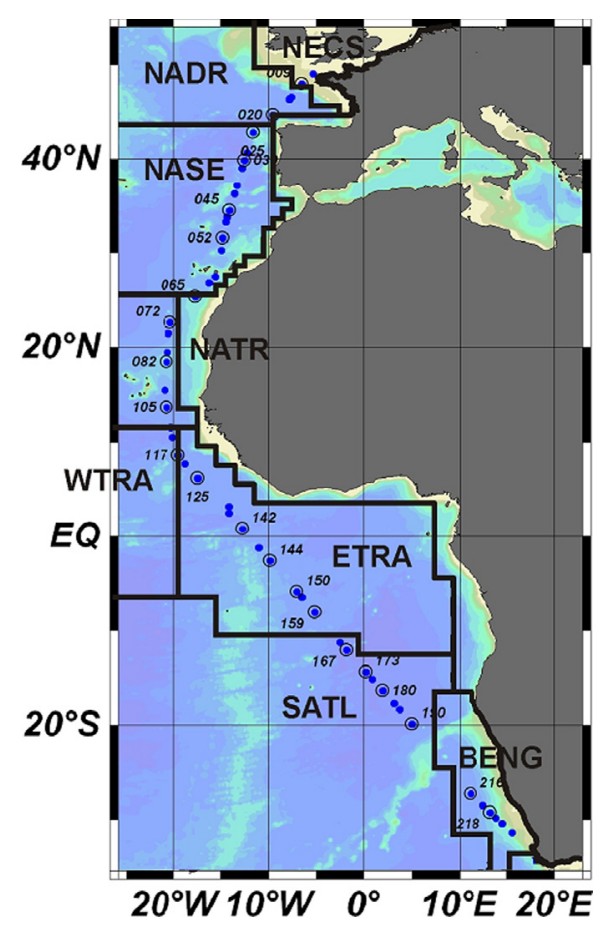

b

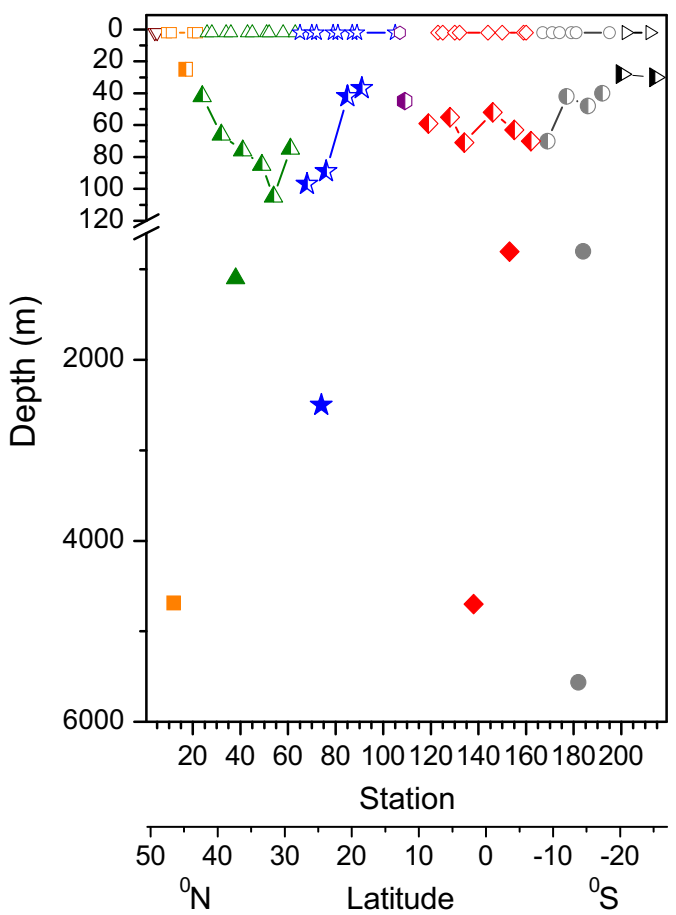

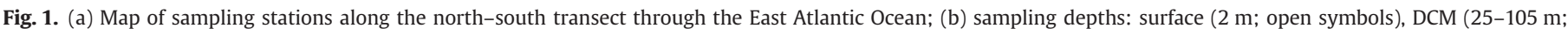

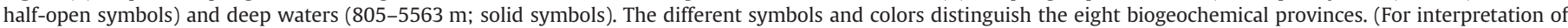
the references to color in this figure legend, the reader is referred to the web version of this article.)

Table 1

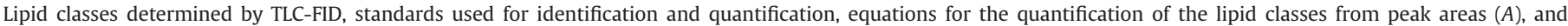
retention times. The solid lines within the table mark the changes of the chromatographic conditions and separation (see methods for details).

\begin{tabular}{|c|c|c|c|c|}
\hline Lipid classes & Standards used & Abbreviations & Equations for quantification to $\mu \mathrm{g}$ & Retention times \\
\hline Hydrocarbons & n-Nonadecane & $\mathrm{HC}$ & $(\mathrm{A} / 1041.5)^{(1 / 1.2242)}$ & 0.055 \\
\hline Wax esters + sterol esters & Stearic acid myristic ester & WE & $(\mathrm{A} / 1052.5 \times 1)^{(1 / 1.3034)}$ & 0.189 \\
\hline Fatty acid methyl esters & Palmitic acid methyl ester & ME & $(\mathrm{A} / 988.99)^{(1 / 1.4293)}$ & 0.230 \\
\hline Fatty ketone ${ }^{*}$ & 1-Hexadecanone & KET & $(\mathrm{A} / 1041.2)^{(1 / 1.3414)}$ & 0.267 \\
\hline Triacylglycerols & Tristearoyl-glycerol & TG & $(\mathrm{A} / 1377.7)^{(1 / 1.4471)}$ & 0.078 \\
\hline Free fatty acids & Stearic acid & FFA & $(\mathrm{A} / 1386.5)^{(1 / 1.4071)}$ & 0.134 \\
\hline Fatty alcohols & 1-Hexadecanol & ALC & $(\mathrm{A} / 956.06)^{(1 / 1.2867)}$ & 0.140 \\
\hline 1,3-Diacylglycerols & 1,3-di(cis-9-octadecenoyl)glycerol & $1,3 \mathrm{DG}$ & $(\mathrm{A} / 218.68)^{(1 / 1.283)}$ & 0.203 \\
\hline Sterols & Cholesterol & & $(\mathrm{A} / 1601.9)^{(1 / 1.507)}$ & 0.227 \\
\hline 1,2-Diacylglycerols & rac-1,2-distearoylglycerol & $1,2 \mathrm{DG}$ & $(\mathrm{A} / 1415.8)^{(1 / 1.3499)}$ & 0.260 \\
\hline Pigments & Chlorophyll $a$ & PIG & $(\mathrm{A} / 1517.2)^{(1 / 1.4510)}$ & 0.121 \\
\hline Monoacylglycerols & 1-Stearoyl-rac-glycerol & MG & $(\mathrm{A} / 1010.5)^{(1 / 1.1532)}$ & 0.239 \\
\hline Glycolipids $^{\mathrm{a}}$ & Monogalactosyl-diglycerol & GL & $(\mathrm{A} / 905.66)^{(1 / 1.4270)}$ & 0.225 \\
\hline Phosphatidylglycerols ${ }^{\mathrm{b}}$ & 1-(3-sn-Phosphatidyl)-rac-glycerol sodium salt & PG & $(\mathrm{A} / 883.54)^{(1 / 1.1283)}$ & 0.138 \\
\hline Phosphatidylethanolamines & 1,2-dimyristoyl-sn-glycero-3-phospho-ethanolamine & $\mathrm{PE}$ & $(\mathrm{A} / 1176.5)^{(1 / 1.1138)}$ & 0.186 \\
\hline Phosphatidylcholines & 1,2-Dioleoyl-sn-glycero-3-phosphocholine & PC & $(\mathrm{A} / 1129)^{(1 / 1.3513)}$ & 0.318 \\
\hline
\end{tabular}

a Glycolipids composed of mono- and di-galactosyldiacylglycerols.

b Phosphatidylglycerols (PG) plus diphosphatidylglycerols (DPG) hereafter termed PG.

* Added as internal standard.

method (Neogi et al., 2011). Briefly, water samples were fixed with formaldehyde (4\%) and prokaryotic cells stained using 4',6-diamidino-2-phenylindole (DAPI) for 30 min (manufacturer's manual, Sigma-Aldrich). The abundance of communities was determined following a standard protocol (Porter and Feig, 1980) with an epifluorescence microscope (DM2500, Leica Microsystems). In each of the microscopic observations prokaryotic cells were enumerated at a magnification of 1000 or more. The cells attached to suspended particles in water samples were counted separately. Each sample was examined in triplicate. The carbon content of the prokaryotic heterotrophs was obtained using a conversion factor of $10 \mathrm{fg} \mathrm{C}$ cells $^{-1}$ (Herndl et al., 2005). 


\subsection{Particulate organic carbon}

Samples for the determination of particulate organic carbon were obtained by filtration of 3-4 L seawater through GF/F glass fiber filters $(0.7 \mu \mathrm{m}$ pore size, Whatman, precombusted for $3 \mathrm{~h}$ at $450{ }^{\circ} \mathrm{C}$ ). The filters were stored at $-20^{\circ} \mathrm{C}$ and later in the home lab dried at $60{ }^{\circ} \mathrm{C}$ for $12 \mathrm{~h}$. Inorganic carbon was removed by acidification, and POC was quantified with an elemental analyzer (Fisons, NA 2100; for details refer to Neogi et al. (2011)).

\subsection{Lipid class analysis}

For the lipid class determination 2-11 L of seawater were filtered through the GF/F filters immediately after sampling. The filters were stored in liquid nitrogen for later lipid extraction and analysis. Particulate lipids were extracted by a modified one-phase solvent mixture of dichloromethane-methanol-water (Bligh and Dyer, 1959). N-hexadecanone was added as internal standard to each sample to estimate the recoveries in the subsequent steps of the sample analysis. The extracts were evaporated to dryness under nitrogen atmosphere and redissolved in $20 \mu \mathrm{L}$ dichloromethane.

Lipid classes were determined by thin-layer chromatographyflame ionization detection (TLC-FID; Iatroscan MK-VI, Iatron, Japan) with a hydrogen flow of $160 \mathrm{~mL} \mathrm{~min}^{-1}$ and an air flow of $2000 \mathrm{~mL} \mathrm{~min}^{-1}$. Lipid classes were separated on Chromarods SIII (SES-Analysesysteme, Germany) and quantified by external calibration with a standard lipid mixture. The standard deviation determined from duplicate runs accounted for $0-12 \%$ of the relative abundance of lipid classes. The determined lipid classes and the standards used (all from Sigma Aldrich) are given in Table 1. Calibrations were performed for each class of compounds at 12 concentrations spanning a range from 0.1 to $3.5 \mu \mathrm{g}$. Data (peak area $(A)$ vs. mass $(m$, in $\mu \mathrm{g}))$ are fitted with exponential functions (Table 1$)$.

The separation scheme involved subsequent elution steps in the solvent systems of increasing polarity (Frka et al., 2011) followed by a subsequent partial burn of Chromarods (for retention times refer to Table 1). HC, WE, ME, and KET were separated with hexane-diethyl ether-formic acid (97:3:0.2, v:v:v) for $28 \mathrm{~min}$. TG and FFA were separated with hexane-diethyl etherformic acid (80:20:0.2, v:v:v) for $30 \mathrm{~min}$. ALC, 1,3DG, ST, and 1,2DG were separated with an additional $20 \mathrm{~min}$ in the previous solvent mixture. PIG and MG were separated with chloroform-acetoneformic acid (95:5:0.6, v:v:v) for $32 \mathrm{~min}$. This was followed by $8 \mathrm{~min}$ in acetone (100\%) to elute GL. Finally, chloroform-methanol-ammonium hydroxide (50:50:5, v:v:v) during 40 min allowed separation of PG, PE, PC, and non-lipid material which remained at the origin. Total lipid concentrations were obtained by summing all lipid classes quantified by TLC-FID.

The contribution of particulate lipids to POC was evaluated by estimation of the organic carbon content in lipids. The 70\% carbon content in lipids was calculated from standards of the three most abundant lipids in this work. The lipolysis index (LI) was calculated as the ratio of the sum of lipid metabolites (ALC+FFA+MG+DG) to the sum of TG, WE, and glyco- and phospholipids (Goutx et al., 2003).

\subsection{Data analysis}

A linear fit was used to analyze correlations between the data with 95\% confidence interval by using ANOVA, Origin 7 software (Origin Lab). Multivariate analyses were performed with Statistica software.

Multivariate statistical analysis was used to elucidate the relationships between lipids and important environmental variables that describe the East Atlantic Ocean surface and DCM waters, i.e. total lipid concentration (lip), concentration of total lipids per Chl $a$ (lip/Chl) and contribution of plankton phospholipids (\%PG), autotrophic plankton glycolipids (\%GL) and plankton and zooplankton reserve lipids (\%TG and \%WE, respectively) as percentages of total lipids. Other data included nutrient concentrations (total inorganic nitrogen (TIN) and phosphate $\left(\mathrm{PO}_{4}{ }^{3-}\right.$ ) (data after Koch and Kattner (2012)), the relative contribution of carbon contents of eukaryotic micro-, nano- and picophytoplankton, and prokaryotic heterotrophs to total plankton carbon (\%micro C, \%nano C, \%pico C, \%pico C and \%het C, respectively).

\section{Results}

All details on the hydrographic conditions and nutrients are presented in Koch and Kattner (2012). Briefly, the highest temperatures and the lowest salinities were measured for NATR to ETRA. The lowest temperatures occurred at the northernmost and southernmost latitudes. The coastal regions of Europe and South Africa and, to a lesser extent, the area of NATR were characterized by higher nutrient concentrations in the surface waters whereas the waters of the remaining transect in the subtropical and tropical regions were oligotrophic. The waters of DCM were characterized by higher nutrient concentrations than surface waters, especially in the NATR to BENG regions.

\subsection{Distribution of plankton}

The plankton cell abundances including prokaryotic heterotrophs, cyanobacteria and eukaryotic nano- and picophytoplankton

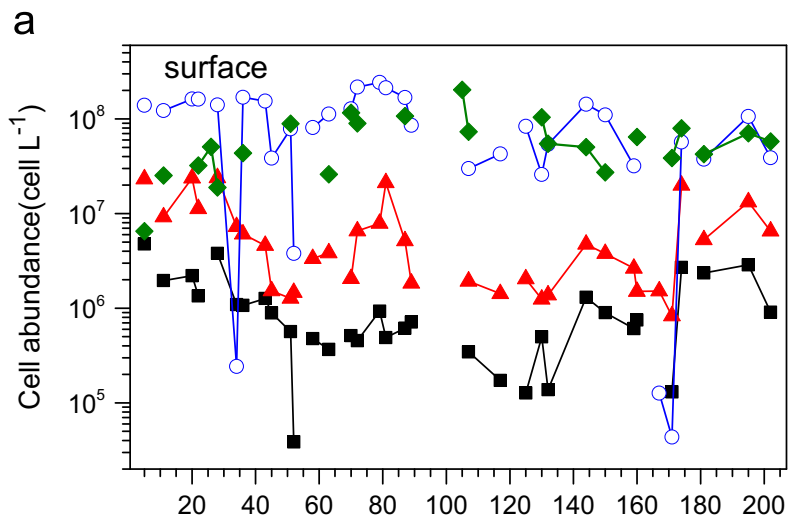

b

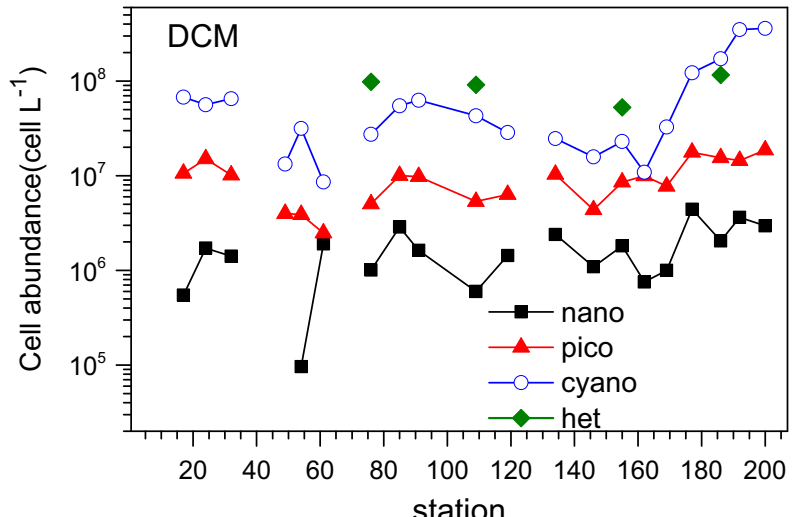

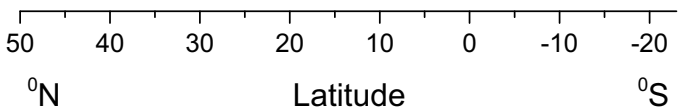

Fig. 2. Cell numbers of prokaryotic heterotrophs (het), eukaryotic nanophytoplankton (nano), eukaryotic picophytoplankton (pico) and cyanobacteria (cyano) along the north-south transect of the East Atlantic in (a) surface and (b) DCM layers. 
for surface and DCM waters are presented in Fig. 2a and b. The cell abundances of heterotrophic prokaryotes ranged from $6.5 \times 10^{6}$ to $2.9 \times 10^{8}$ cells $\mathrm{L}^{-1}$ in the surface waters and from $5.3 \times 10^{7}$ to $1.2 \times 10^{8}$ cells $\mathrm{L}^{-1}$ in the DCM (data obtained for four samples). Total numbers of cyanobacteria ranged from $4.4 \times 10^{4}$ to $2.4 \times 10^{8}$ cells L $^{-1}$ in the surface waters and from $8.6 \times 10^{6}$ to $3.6 \times 10^{8}$ cells L $^{-1}$ in the DCM. In the surface waters eukaryotic nanophytoplankton varied from $3.9 \times 10^{4}$ to $4.8 \times 10^{6}$ cells L $^{-1}$, while eukaryotic picophytoplankton varied from $8.3 \times 10^{5}$ to $2.4 \times 10^{7}$ cells $\mathrm{L}^{-1}$ with lowest numbers in the area north of the Equator (ETRA) where high surface temperatures and dissolved organic carbon concentrations and low salinities were observed (Koch and Kattner, 2012). In the DCM eukaryotic nano- and picophytoplankton cell abundances ranged from $9.6 \times 10^{4}$ to $4.4 \times 10^{6}$ cells $\mathrm{L}^{-1}$ and from $2.5 \times 10^{6}$ to $1.9 \times 10^{7}$ cells $\mathrm{L}^{-1}$, respectively.

\subsection{Distribution of pigments}

The surface Chl $a$ concentrations ranged from about 0.08 to $1.24 \mu \mathrm{g} \mathrm{L}^{-1}$ (average $0.3 \mu \mathrm{g} \mathrm{L}^{-1}$ ), being the highest in the NATR

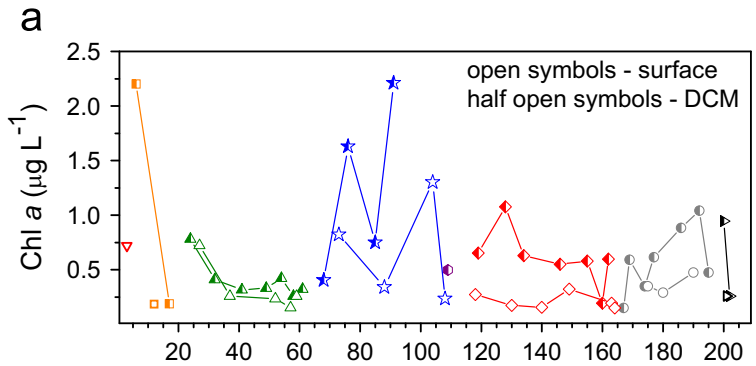

b

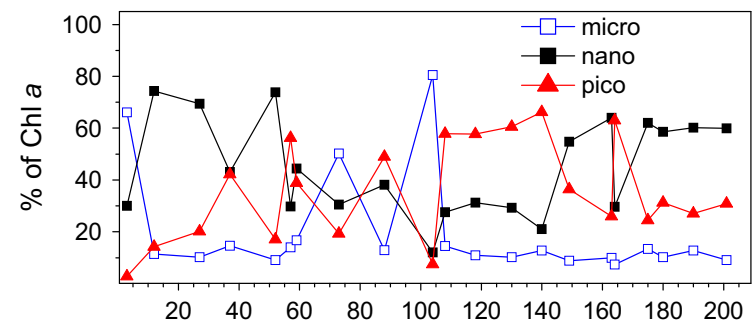

C

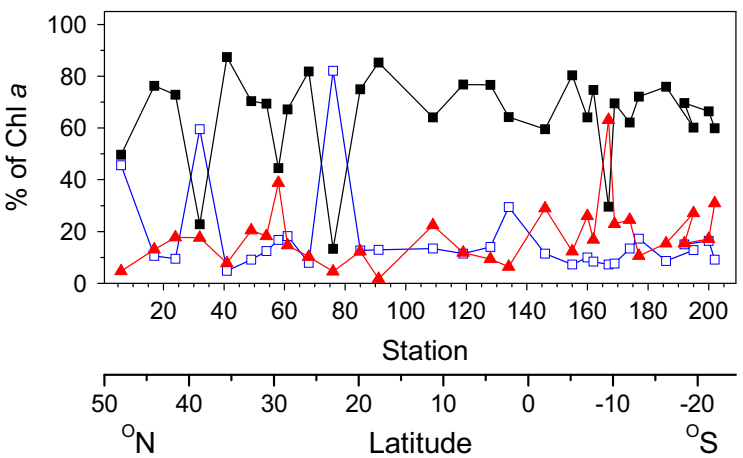

Fig. 3. Chlorophyll $a$ distribution (a) in surface and DCM (the different symbols and colors distinguish the eight biogeochemical provinces). The contribution of phytoplankton size classes: eukaryotic micro- (micro), nano- (nano) and picophytoplankton (pico) to Chl $a$ in (b) surface and (c) DCM layers. (For interpretation of the references to color in this figure legend, the reader is referred to the web version of this article.) province (Fig. 3). In the DCM, Chl $a$ concentrations varied between 0.09 and $2.14 \mu \mathrm{g} \mathrm{L}^{-1}$ (average $0.91 \mu \mathrm{g} \mathrm{L}^{-1}$ ). The lowest concentrations were found in the NASE province where lower phosphate and nitrate concentrations also occurred (Koch and Kattner, 2012).

Concentrations of key chemotaxonomic marker pigments were summed to facilitate a broad assessment of the relative importance of the three phytoplankton classes (Fig. 3b, modified after Taylor et al. (2011), and Fig. 3c). Surface waters were dominated in relative chlorophyll contribution by eukaryotic pico- and nanophytoplankton throughout most of the transect. Eukaryotic nanophytoplankton was the most dominant phytoplankton fraction in the DCM with a relatively uniform contribution to total pigments. The lowest contribution was derived from eukaryotic microphytoplankton with substantially increased values in the NECS and NATR.

The concentrations of Phaeophytin-a (Phyt-a) and Phaeophytin-b (Phyt-b), degradation pigments of Chl $a$ and $\mathrm{Chl} b$, respectively, were below the detection limit for most of the samples. Thus, Phyt-a was only detected in the surface of stations 65 and 144 with concentrations of 48.0 and $10.9 \mathrm{ng} \mathrm{L}^{-1}$, respectively and in the DCM of station 49 with $34.5 \mathrm{ng} \mathrm{L}^{-1}$, where also Phyt-b was measured in a concentration of $44.9 \mathrm{ng} \mathrm{L}^{-1}$.
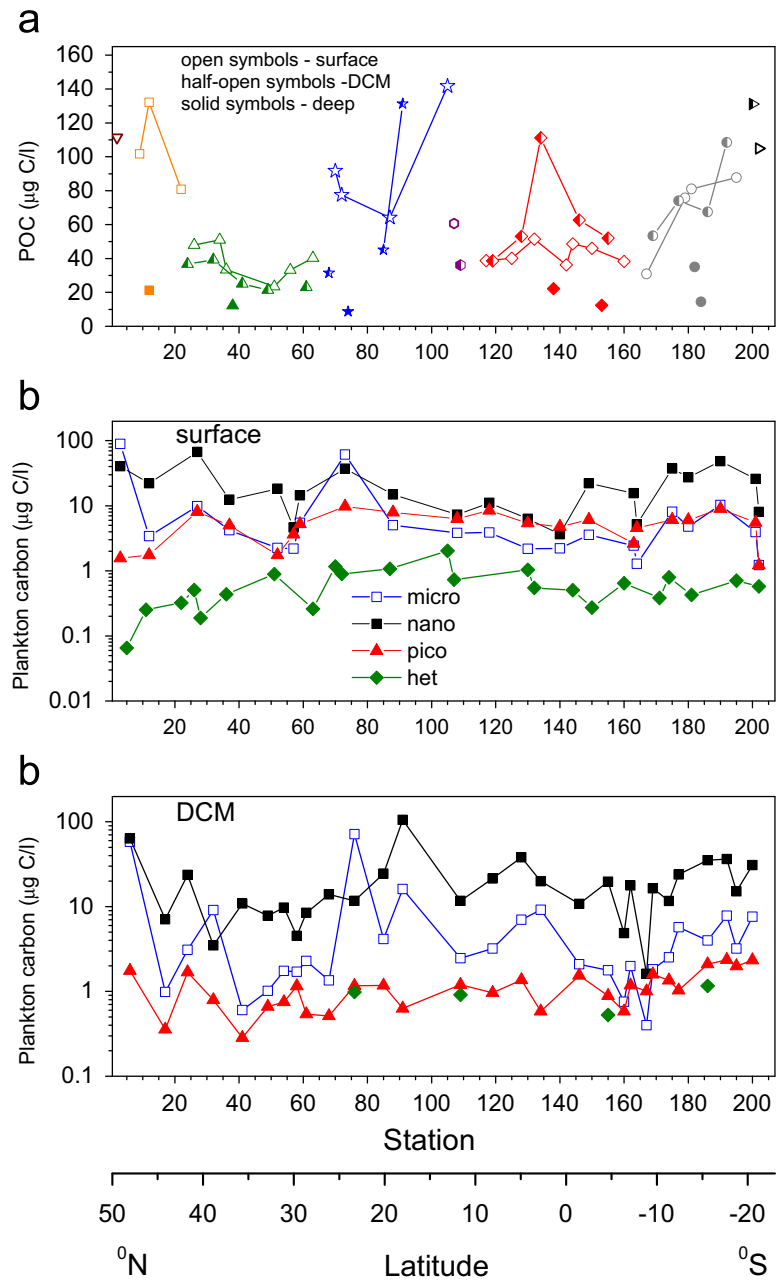

Fig. 4. Particulate organic carbon (POC) (a) distribution (the different symbols and colors distinguish the eight biogeochemical provinces). Distribution of prokaryotic heterotroph (het), eukaryotic micro- (micro), nano- (nano) and picophytoplankton (pico) carbon content in (b) surface and (c) DCM layers. (For interpretation of the references to color in this figure legend, the reader is referred to the web version of this article.) 


\subsection{Distribution of particulate organic carbon and plankton carbon}

Similar concentrations of POC (21-131 $\left.\mu \mathrm{g} \mathrm{C} \mathrm{L}^{-1}\right)$ were detected in the surface and DCM layers. The lowest POC concentration (8.8 $\mu \mathrm{g} \mathrm{C} \mathrm{L}^{-1}$ ) was measured for the sample at $1100 \mathrm{~m}$ depth at station 74 (NATR) (Fig. 4a). The distribution of POC strongly paralleled that of Chl $a$, being higher in the northernmost and southernmost latitudes and in NATR. The correlations between POC and Chl $a$ were significant for the surface $(r=0.71, p=0.0002$, $n=21)$ and DCM $(r=0.64, p=0.0020, n=19)$.

The calculated carbon content of eukaryotic micro-, nano- and picophytoplankton, and prokaryotic heterotrophs is shown in Fig. 4b and c. Eukaryotic microphytoplankton carbon concentrations ranged from 1.2 to 89.1 (average 12.4) $\mu \mathrm{g} \mathrm{C} \mathrm{L}^{-1}$ in the surface and from 0.4 to 71.7 (average 8.1) $\mu \mathrm{g} \mathrm{CL}^{-1}$ in the DCM layer. Eukaryotic nanophytoplankton carbon was similar in the surface and DCM waters averaging 20.0 (3.6-67.3) and 21.1 (1.6-105.8) $\mu \mathrm{g} \mathrm{C} \mathrm{L}{ }^{-1}$, while eukaryotic picophytoplankton carbon was clearly lower varying between 1.2 and 9.8 (average 5.2) $\mu \mathrm{g} \mathrm{C} \mathrm{L}^{-1}$ in the surface and 0.2-2.4 (average 1.2) $\mu \mathrm{g} \mathrm{C} \mathrm{L}^{-1}$ in the DCM. The contribution of carbon derived from prokaryotic heterotrophs was low, with 0.1-2.0 (average 0.6) $\mu \mathrm{g} \mathrm{C} \mathrm{L^{-1 }}$ at the surface and similar values in the DCM. The contribution of eukaryotic micro-, nanoand picophytoplankton, and prokaryotic heterotroph carbon to POC was on average $7.3 \%, 33.4 \%, 10.0 \%$ and $1.3 \%$, respectively, at the surface and $7.8 \%, 40.7 \%, 2.2 \%$, and $1.8 \%$, respectively, in the DCM.

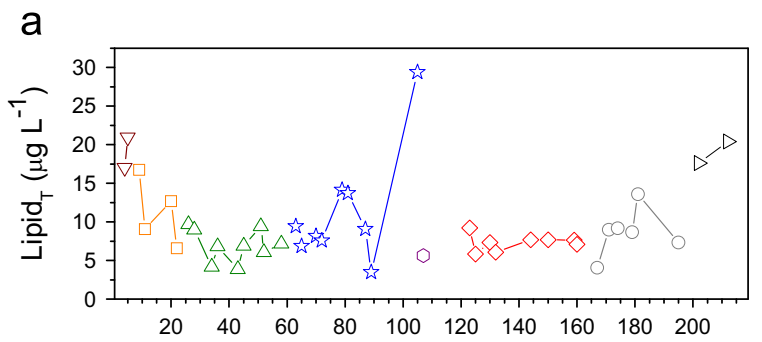

b

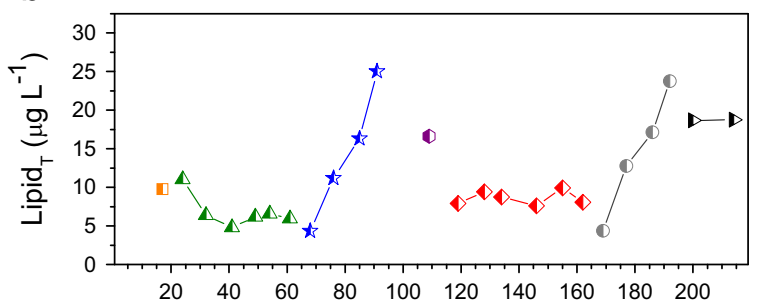

C

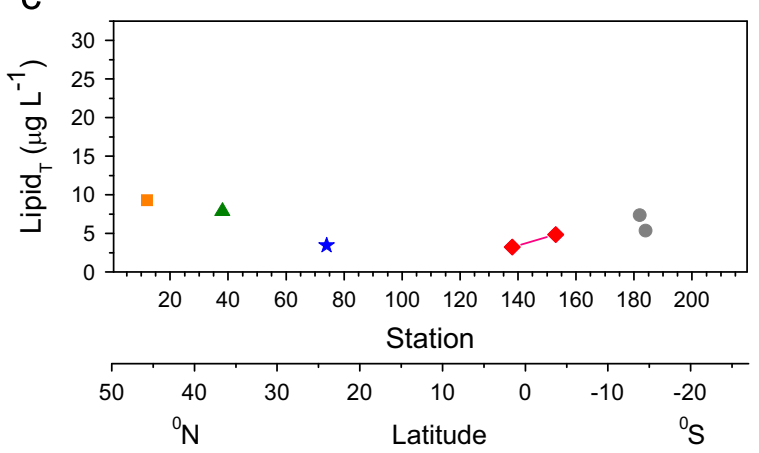

Fig. 5. Distribution of the total lipid concentration ( $\operatorname{lipid}_{\mathrm{T}}$ ) in (a) surface, (b) DCM and (c) deep waters (the different symbols and colors distinguish the eight biogeochemical provinces). (For interpretation of the references to color in this figure legend, the reader is referred to the web version of this article.)

\subsection{Distribution of particulate lipids}

The concentrations of total particulate lipids ranged from 3.2 to $29.4 \mu \mathrm{g} \mathrm{L}^{-1}$ with comparatively lower values in deep water samples (average 10.5, 11.3 and $6.0 \mu \mathrm{g} \mathrm{L}^{-1}$ at surface, DCM, and in deep waters, respectively) (Fig. 5). The concentrations were higher in waters at the most northern and southern latitudes as well as in the NATR province. This distribution resembled those of Chl $a$ and POC. Highly significant correlations were revealed between total particulate lipid concentrations and Chl $a$ (as proxy for total phytoplankton abundance) for the surface $(r=0.71$, $p=0.0002, n=21)$ and DCM $(r=0.67, p=0.0003, n=23)$ samples. The same result was obtained for the concentration of total particulate lipids and POC for the surface $(r=0.75, p<0.0001$, $n=22)$ and DCM $(r=0.68, p=0.0008, n=19)$ samples. At the surface a positive correlation was also observed between total particulate lipid concentrations and eukaryotic microphytoplankton carbon content $(r=0.79, p<0.0001, n=21)$ as well as eukaryotic nano- and picophytoplankton carbon content $(r=0.67$, $p=0.0011, n=20 ; r=0.61, p=0.0032, n=20$, respectively) in the DCM layer.

Lipid contributions to POC (\%) were between 5.7\% and $29.8 \%$ with an average of $12.6 \%$ at the surface and between $5.5 \%$ and $33.3 \%$ with an average of $14.4 \%$ in the DCM. The lowest contributions in the surface water were found for the NATR samples. The DCM samples showed lower lipid proportions of POC throughout the track from the ETRA to the BENG provinces. The highest lipid contents were generally determined for the deep water samples (Fig. 6).

To obtain an estimate on the quantity of lipid synthesized per unit Chl $a$ the total lipid content per Chl $a$ concentration $\left(\operatorname{lipid}_{\mathrm{T}} / \mathrm{Chl} a\right)$ (Fig. 7a) was calculated for the surface and the DCM samples. The most striking features were: higher ratios mainly observed for the surface layer in comparison to DCM, lower values in the NATR province (stations 65-105), and decreasing ratios in the DCM samples of the provinces richer in nutrients (ETRA to BENG; stations 119-214). Although not statistically significant, a decreasing trend of the $\operatorname{lipid}_{\mathrm{T}} / \mathrm{Chl} a$ ratio was observed for stations with higher nutrient concentrations.

\subsection{Composition of particulate lipids}

The proportions of the major lipid classes of total lipids are shown in Fig. 8. In all provinces and depths, glycolipids formed the

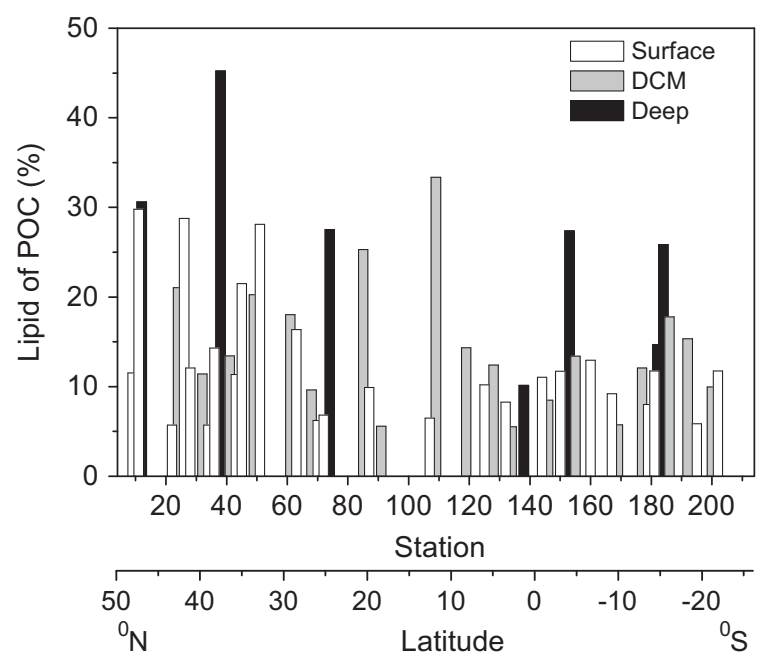

Fig. 6. Distribution of the lipid proportions to POC (\%) in (a) surface (white), (b) DCM (gray) and (c) deep waters (black). 
a

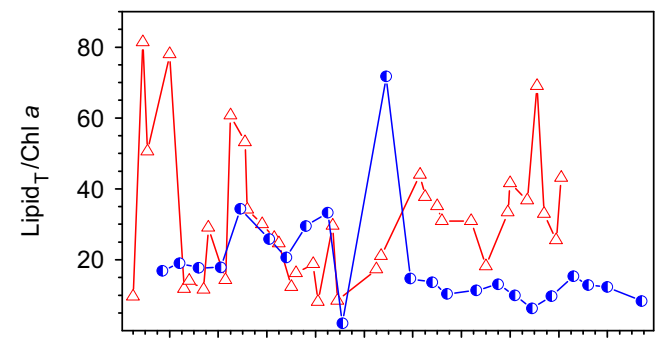

C

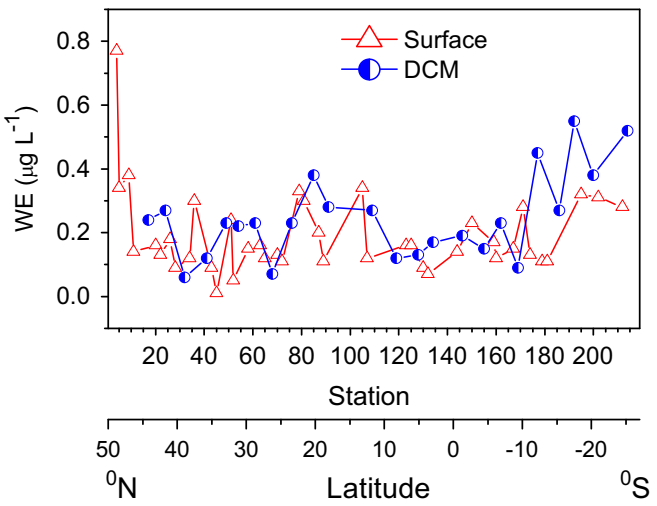

b

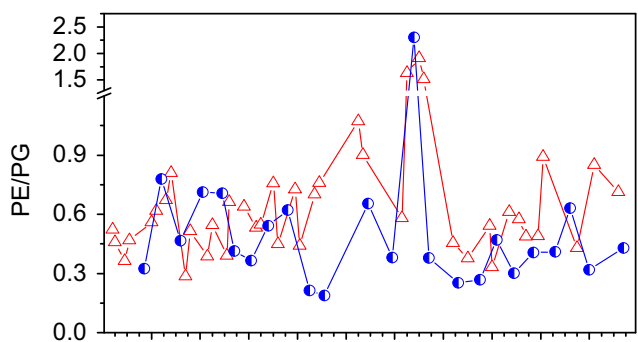

d

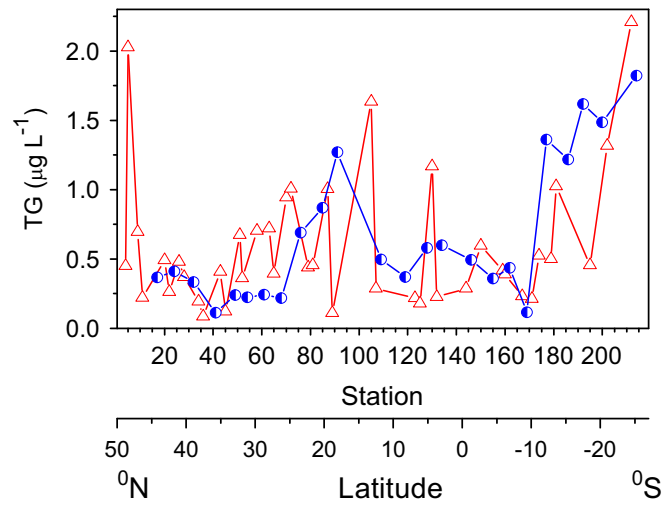

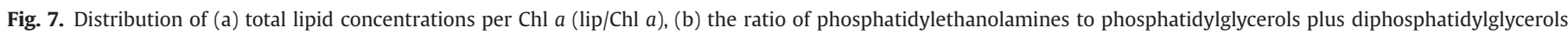
(PE/PG), (c) the concentration of wax esters (WE) and (d) of triacylglycerols (TG) in surface (triangles) and DCM (circles) layers.
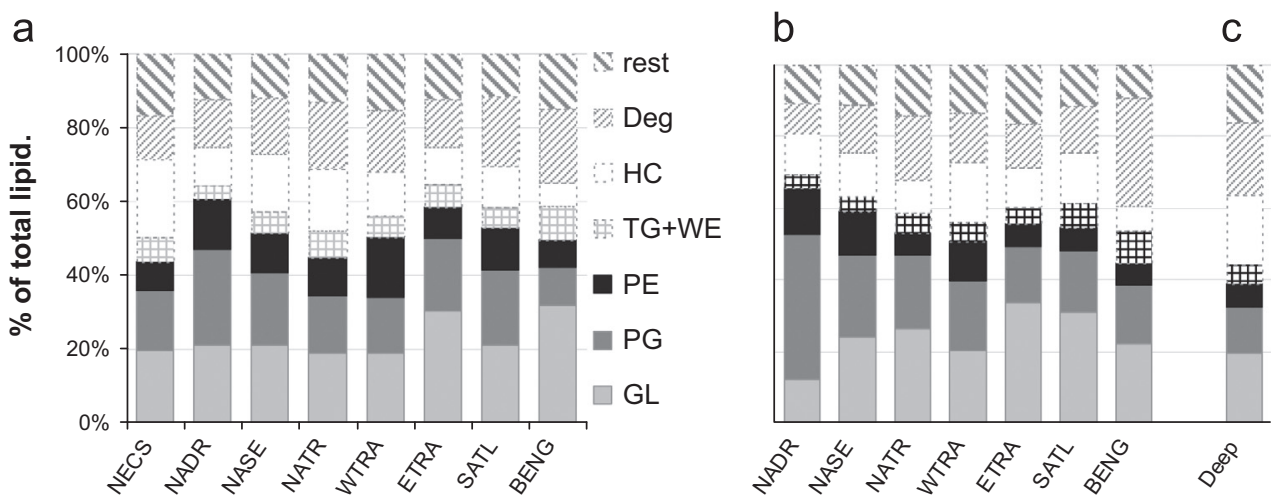

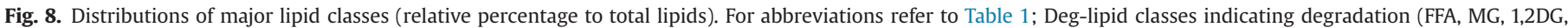
1,3DG, and ALC); rest-sum of remaining lipid classes. (a) surface, (b) DCM and (c) Deep.

most abundant lipid class (12-33\%). The second most abundant class was PG in the surface and the DCM samples (10-29\%) followed by PE (2-25\%), and HC in the deep waters (3-42\%). We discuss PG as a rough collective marker of autotrophic plankton and of heterotrophic bacteria presence, hereafter termed plankton marker, since their main origin is autotrophic plankton (Guschina and Harwood, 2009), whereas heterotrophic bacteria are the dominant sources of PE (Van Mooy and Fredricks, 2010).

In the surface layer the concentrations of the lipids which are dominant in membranes were highest for GL $\left(0.5-8.2 \mu \mathrm{g} \mathrm{L}^{-1}\right)$ followed by PE (0.3-4.4 $\left.\mu \mathrm{g} \mathrm{L}^{-1}\right)$ and PG (0.5-4.1 $\left.\mu \mathrm{g} \mathrm{L}^{-1}\right)$, and only low levels of PC and ST were found. In the DCM layer the concentrations were similar (Supplementary tables). The PE/PG ratio was determined to distinguish between the contribution of phytoplankton and bacteria lipids in the total lipid pool (Fig. 7b). According to Goutx et al. (1993), the PE/PG ratio may be used as an index of the contribution of bacterial lipids to the organic matter pool. Higher PE/PG ratios were measured for the surface (0.290.91 ) than for the DCM samples (0.19-2.30). The highest ratios were measured for surface samples in the WTRA and ETRA (stations 107-162) and for DCM samples in the NASE and WTRA provinces (stations 65-109).

In the deep ocean waters PG, GL, PC, ST, and PE concentrations were $0.3-1.3,0.3-3.2,0.1-0.3,0.1-0.2,0.1-0.3 \mu \mathrm{g} \mathrm{L}^{-1}$, respectively. The largest decrease in concentration was measured for PG, PE and ST in deep samples in comparison to the surface waters.

The concentration of the plankton storage lipids, WE and TG (Supplementary tables), were on average 0.19 and $0.59 \mu \mathrm{g} \mathrm{L}^{-1}$ in the surface and 0.25 and $0.65 \mu \mathrm{g} \mathrm{L}^{-1}$ in the DCM samples, respectively. Since the WE TLC band contains only small amounts of stearyl esters (Hudson et al., 2001) it is referred to as zooplankton wax esters in the following. WE exhibited the highest 
concentrations in the samples from the most northern and southern latitudes and the NATR (Fig. 7c). The WE distribution followed that of PG as shown by the significant correlation in the surface and DCM samples $(r=0.41, p=0.0053, n=41$ and $r=0.44$, $p=0.0175, n=24$, respectively). The concentrations of WE (on average $0.32 \mu \mathrm{g} \mathrm{L}^{-1}$ ) were higher in deep water samples than in the surface layers. The average contribution of TG to total particulate lipids was highest in the surface (6.3\%), lower in the DCM (5.3\%) and lowest in the deep layer samples (4.8\%). Higher TG concentrations were observed in the nutrient richer provinces, NECS, BENG and NATR, in the surface and at the nutrient richer stations of the provinces SATL and BENG (stations 167-214) in the DCM (Fig. 7d).

The concentration of lipids indicating degradation, FFA, MG, 1,2DG, 1,3DG, and ALC, were low and similar in the surface and the DCM samples, ranging for FFA from 0.2 to $5.4 \mu \mathrm{g} \mathrm{L}^{-1}$ and for the other lipid classes from 0.0 to $0.7 \mu \mathrm{g} \mathrm{L}^{-1}$ (Supplementary tables).

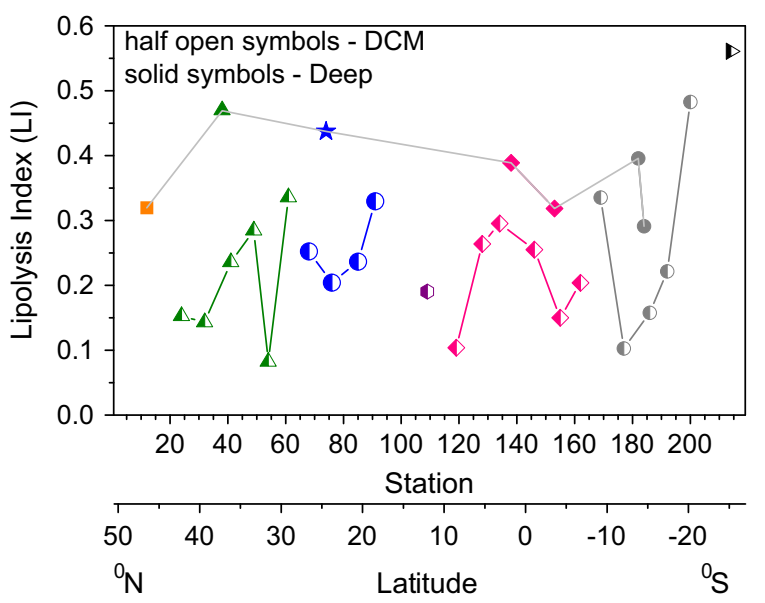

Fig. 9. Lipolysis Index (LI) variations in the DCM (half-open symbols) and deep waters (solid symbols) (the different symbols and colors distinguish the eight biogeochemical provinces). LI data for the surface are not presented as they overlap with LI data from DCM. (For interpretation of the references to color in this figure legend, the reader is referred to the web version of this article.)

a

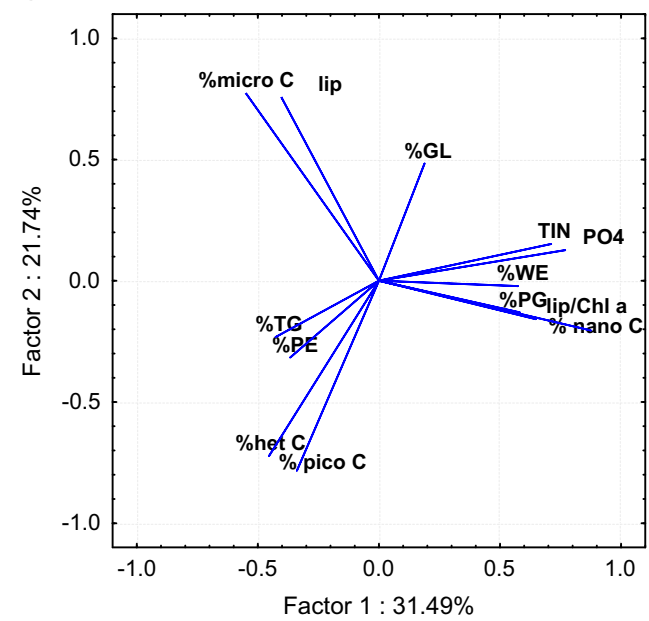

Their concentrations were even lower in the deep samples with up to $0.1 \mu \mathrm{g} \mathrm{L} \mathrm{L}^{-1}$, except for FFA with $0.4-1.9 \mu \mathrm{g} \mathrm{L}^{-1}$. These degradation indicators contributed more to the lipid pool of the deep than of the surface and DCM samples. Therefore, the values of LI for the deep samples were generally higher than in samples from the upper water column (Fig. 9). The LI values from the surface and the DCM ranged from 0.11 to 0.54 (average 0.27 ) and from 0.08 to 0.56 (average 0.24 ), respectively, while for the deep samples LI ranged from 0.29 to 0.47 (average 0.37 ). The LI data of deep samples are significantly different at the 0.05 confidence level to those of the surface and DCM LI data.

\subsection{Multivariate statistical analysis}

Principal component analyses of the surface and DCM samples are presented in Fig. 10. The first two principal components of the surface samples (Fig. 10a) explained 53\% of the total variability among the 14 variables, where the first component (PC1) contributed $31 \%$ of the total variance and the second component (PC2) contributed $22 \%$. The greatest positive PC1 loadings had relative contribution from eukaryotic nanophytoplankton to total plankton carbon, TIN, $\mathrm{PO}_{4}, \% \mathrm{WE}, \% \mathrm{PG}$ and lip/Chl $a$. This indicates that eukaryotic nanophytoplankton fraction the best responded on the availability of nutrients and that eukaryotic nanophytoplankton accumulated more lipids per Chl $a$. The increase of WE parallels the increase of eukaryotic nanophytoplankton carbon. Total lipid concentrations and microphytoplankton abundance had the greatest positive effect on PC2 indicating that microphytoplankton was the most important factor for lipid abundance.

For the DCM samples, the first two principal components PC1 (47\%) and PC2 (38\%) (Fig. 10b) explained 85\% of the total variability among the 14 variables. The increase in the contribution of glycolipids to the lipid pool in the DCM samples was inversely related to the contribution of phospholipids. The relative contribution from eukaryotic picophytoplankton and prokaryotic heterotrophs to total plankton carbon, total lipids, lip/Chl, \%PG and \%PE predominated in the high negative values of PC1. Microphytoplankton and \%WE had the greatest positive effect on PC2 which were significantly correlated. Total lipids, the relative contribution from eukaryotic nano- and picophytoplankton, TIN and $\mathrm{PO}_{4}$ showed considerably negative values in the PC2. b

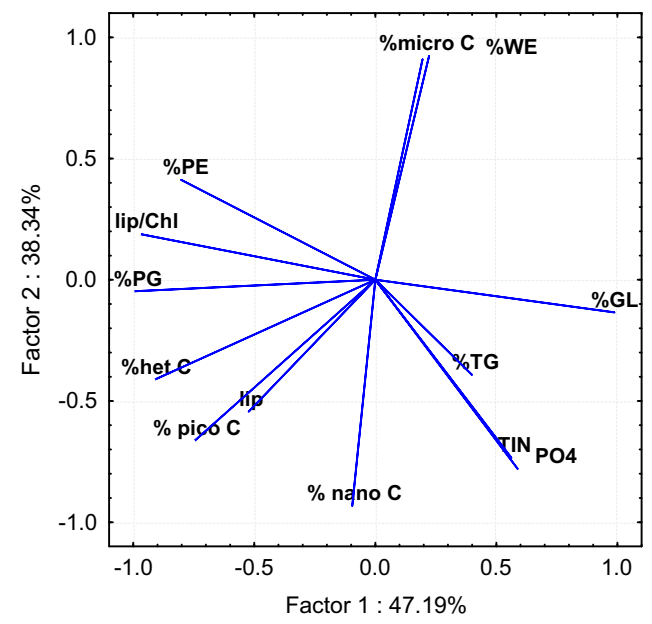

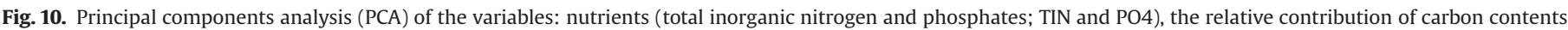

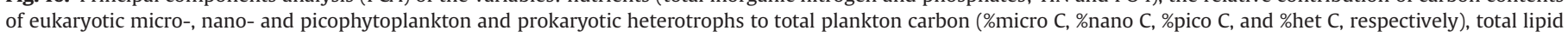

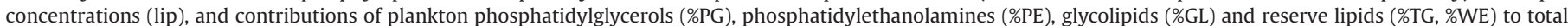
lipid concentrations for the (a) surface and (b) DCM layers. 


\section{Discussion}

\subsection{Ecological drivers of lipid synthesis}

Particulate organic matter composition is highly variable especially in studies over long distances. It contains eukaryotes and prokaryotes with variable species composition and considerable amounts of detrital material, decaying and senescent cells. The particulate matter of our latitudinal transect, that covered many different trophic states in the surface and DCM layers, was characterized by almost order of magnitude variability in the concentration of total lipids. The eukaryotic microphytoplankton was the most important factor for increasing lipid levels at the surface. In the DCM layer both eukaryotic pico- and nanophytoplankton were the main contributors to the lipid pool. This is in accordance to Guschina and Harwood (2009) who found that in the marine environment the origin of lipids is mainly from autotrophic plankton.

Many factors influence the lipid abundance in oceans. Since large cell sized plankton has more lipids than small ones particulate matter is lipid-richer in regions rich in microphytoplankton biomass than those dominated by nano- or, even more, by picophytoplankton. Indeed, we found higher lipid concentrations in provinces with increasing eukaryotic microphytoplankton cell abundance and thus higher carbon proportions to total plankton carbon, i.e. at the most northern and southern latitudes as well as in the NATR. However, concentrations of the particulate lipids $\left(3.2-29.4 \mu \mathrm{g} \mathrm{L}^{-1}\right)$ in our East Atlantic Ocean study were lower (Fig. 5) compared to Iatroscan measured marine lipid concentrations from coastal regions of the NW Atlantic $\left(28-58 \mu \mathrm{g} \mathrm{L}^{-1}\right.$, Parrish et al., 1988), Bedford Basin (70-140 $\mu \mathrm{g} \mathrm{L}^{-1}$, Parrish, 1987), west Mediterranean Sea (3-84 $\mu \mathrm{g} \mathrm{L}^{-1}$, Gérin and Goutx, 1994) and Adriatic Sea (17-370 $\mu \mathrm{g} \mathrm{L}^{-1}$, Penezić et al., 2010; Frka et al., 2011).

The highest lipid concentrations, coinciding with the highest POC and Chl $a$ values, were observed at the more coastal stations in the Atlantic coastal provinces NECS and BENG and NATR. In the NECS, nutrient-rich river plumes and nutrient-upwelling by progressive waves increase the primary production. The BENG area is characterized by significant particulate atmospheric deposition and intense upwelling at $21-24^{\circ} \mathrm{S}$ stimulating productivity (Longhurst, 2007). In the NATR upwelling region (at $\sim 20^{\circ} \mathrm{N}$ ) pulses of Saharan dust moving westward across the Atlantic Ocean depose soluble Fe which plays an important role for the ecosystem (Sarthou et al., 2003). Fe is an essential micronutrient for phytoplankton and known to limit primary production in large parts of the world's oceans (Martin and Fitzwater, 1988). In the euphotic zone of the nutrient richer regions (NECS, NATR, and BENG) small phytoplankton cells are accompanied by larger cells as nutrient availability increases (Irwin et al., 2006).

The lipid content of organisms is highly variable and depends on physical, chemical and biological conditions in the sea. The main lipid contribution to the POC pool of the East Atlantic particulate matter came from phytoplankton cells, accounting for $50 \%$ of the POC in the surface and the DCM layers. On average phytoplankton contained $17 \%$ of lipids per dry mass, while diatoms accounting for up to $25 \%$ of lipids (Shifrin and Chishilm, 1981). The contribution of heterotrophic prokaryotes' carbon to POC in the East Atlantic was only minor, between $1 \%$ and $2 \%$, and the lipid content of marine bacteria is also low varying from $1.7 \%$ to $7.3 \%$ of organic carbon (Goutx et al., 1990). Contributions of other planktonic organisms (not analyzed for this cruise) were also small. Karayanni et al. (2005) found the biomass of ciliated protozoa and heterotrophic nanoflagellates in the East Atlantic to be a few $\mu \mathrm{g} \mathrm{C} \mathrm{L}{ }^{-1}$ and less than $1 \mu \mathrm{gC} \mathrm{L}^{-1}$, respectively. The low amounts of WE in our study indicated only a minor contribution of larger zooplankton known to synthesize WE in contrast to the small subtropical and tropical species which do not store lipids (Kattner and Hagen, 2009).

In addition to the influence of nutrient availability on the phytoplankton composition, nutrient depletion is also favorable to enhancing lipid synthesis (Shifrin and Chishilm, 1981; Smith et al., 1997; Frka et al., 2011). The higher ratios of lipids to Chl a (Fig. 7a) suggest enhanced lipid biosynthesis in the nutrient poorer regions of our study. Phytoplankton may also overcome nutrient deficiency by the preferential synthesis of specific lipid classes. In oligotrophic oceans, the picophytoplankton species Prochlorococcus, for example, adapts to phosphorus deficiency by the synthesis of sulfoquinovosyldiacylglycerol, a lipid that contains a sulfo instead of a phosphate group (Van Mooy et al., 2006). Replacement of membrane phospholipids by non-phosphorus containing GL represents an effective phosphate-conserving mechanism in many organisms during phosphate limitation, including photosynthetic bacteria, algae and higher plants (e.g., Benning et al., 1995; Andersson et al., 2003). Enhanced synthesis and accumulation of glycolipids was found during nutrient depletion in a mesotrophic coastal sea (Frka et al., 2011; Gašparović et al., 2013). The high concentrations of glycolipids found in the surface and DCM layers, the increase of GL versus PG and the relation of GL with smaller cell sized phytoplankton were an indication of the oligotrophic conditions even in the DCM layer where light limitation may also affect the lipid production.

An enhanced accumulation of storage lipids (TG) has been observed during nitrogen stress for marine diatoms (Parrish and Wangersky, 1987), during bloom decay (Parrish, 1987) and during oligotrophication in the NW Mediterranean (Bourguet et al., 2009). However, we observed an increase of TG to total lipids in the nutrient richer provinces. These accumulated TG may be used for the synthesis of other molecules that are necessary for cell functioning, e.g., glycolipids in the chloroplast membranes (Khozin-Goldberg et al., 2005).

\subsection{Lipid composition as part of the East Atlantic biogeochemistry}

Particulate lipids in oceanic waters are mainly of autochthonous origin. Following cell death they are released into the surrounding water as non-living particles and dissolved lipids. Their composition can give information on whether lipids are freshly synthesized by the present plankton communities or more degraded (Goutx et al., 2003). The dominance of phospholipids and glycolipids, the photosynthetic membrane lipids of phytoplankton and cyanobacteria (Guschina and Harwood, 2009, Fig. 8), indicated that considerable amounts of lipids in the East Atlantic originated from living marine plankton. Accordingly, the estimated values of LI for the surface and DCM samples (Fig. 9) were low also indicating a dominance of freshly synthesized lipids. This was supported by the absence of phaeopigments in the particulate organic matter. Much higher LI, often higher than 1, were reported for particulate lipids collected in September at the Mediterranean side of the Strait of Gibraltar (Gómez et al., 2001). However, comparable LI values (0.21-0.39) were obtained in the northwestern Mediterranean Sea during the transition from the end of a phytoplankton bloom to pre-oligotrophic conditions in May. Here, LI values, absence of phaeopigments, together with a high dominance of plankton phospholipids and glycolipids indicate a high contribution of active phytoplankton to POM (Van Wambeke et al., 2001). Another explanation for lower LI values can be low bacterial activity on the particulate lipids. Indeed, Neogi et al. (2011) observed that dissolved organic carbon is the more important source of carbon for oceanic bacterial growth and survival than POC in the East Atlantic surface waters. A slightly higher LI indicated slightly higher lipid degradation in the surface compared to the DCM layer. This can be due to bacterial and photochemical 
abiotic degradation because of the high light conditions (Christodoulou et al., 2009). The composition of fatty acids (data not shown) did not support this small difference in the LI. However, it evidenced the general freshness of POM in the surface and DCM layers. High proportions of polyunsaturated fatty acids (PUFA) stand for freshness and living cells, whereas high proportions of saturated fatty acids for highly degraded material since PUFA are easily degraded in decaying cells and detritial material (e.g. Hama, 1999). Particularly in the surface layer of the NATR and SATL regions, PUFA accounted for up to $20 \%$ of total fatty acids (notably 18:4(n-3) and 22:6(n-3) typical for non-diatom phytoplankton), whereas proportions were clearly lower in the tropical ETRA indicating possible photochemical degradation.

Elevated values of the surface layer PE/PG ratio (Fig. 7b) suggest a contribution of bacteria to the plankton lipids (Goutx et al., 1993) being an obvious source of lipids at stations $107-132\left(3.2-11.6^{\circ} \mathrm{N}\right)$. This is in accordance with the highest bacterial activity in surface waters of the highly stratified region between 0 and $15^{\circ} \mathrm{N}$ (Neogi et al., 2011; Flerus et al., 2012). The lower PE/PG ratios in the DCM layer suggest phytoplankton was a more important source of membrane lipids. Nevertheless, the significant correlation between the concentration of total lipids and Chl $a$ found for both productive layers implies that phytoplankton was the main source of lipids. Therefore, some smaller differences in lipid concentrations between the surface and the DCM samples were mainly due to the difference in phytoplankton size-classes (micro, nano, pico) and bacteria rather than in organic matter degradation processes.

Among other factors, zooplankton predation structures the ecosystem. WE are the main storage lipids in large zooplankton species of polar and partially of temperate and upwelling regions contributing even up to $90 \%$ to total lipids whereas in the small low latitude copepods WE are scarce (Kattner and Hagen, 2009). This is in accordance with the higher WE amounts only found at the northern- and southernmost stations with lower temperatures (Koch and Kattner, 2012). The concentration of WE followed that of the plankton marker (PG) implying better feeding conditions in regions with a more abundant plankton community.

\subsection{Lipid changes from surface to depth}

The comparison between lipid concentration and composition of particulate organic matter from the upper productive layers and the deep ocean waters provides information about the relative reactivity and preservation potential of lipid classes. However, due to the restricted number of samples, including various depths, we discuss only general changes regarding their lipid contribution and composition. Lipids are less degradable biochemical compounds compared to other major groups, carbohydrates and proteins (Harvey et al., 1995). Indeed, higher lipid contributions to POC in deep waters indicated an organic matter-selective degradation that emphasizes the more stable nature of lipids. In accordance with our findings Hwang and Druffel (2003) found that selective accumulation of the lipids is likely to occur in the water column as POC sinks. However, this is controversially discussed in the literature. A strong decrease of lipids in POC with depth has been reported by Wakeham et al. (1997) and Loh et al. (2008). Discrepancies may be related to differences in lipid measurements, e.g. determination of total lipid, lipid classes determined or considered, etc. Even similar concentrations of total particulate lipids were found in the deep and upper water column waters of the NADR and NASE regions (stations 24-63). However, the opposite was found in the ETRA province (stations 119-162) where the concentration of lipids in deep samples decreased to about $40 \%$ of that in the surface and the DCM layers.

The lipid carbon baring the highest potential for export and preservation in the deep East Atlantic was in the form of hydrocarbons, free fatty acids and glycolipids (Fig. 8c). The dominance of $\mathrm{HC}$ can be expected as they are poorly degradable and thus selectively preserved (Wakeham et al., 1997). Also, HC are degradation products of catabolism or diagenesis of biomacromolecules. The large contribution of GL in deep waters is due to the relative resistance to degradation (Tegelaar et al., 1989). Accordingly, Schouten et al. (2010) calculated that a major fraction of GL biosynthesized in the upper water column can potentially reach deep-sea surface sediments. The proportion of phospholipids (PG, $\mathrm{PE}$, and $\mathrm{PC}$ ) of total lipids decreased significantly from the productive layers to the deep waters (Supplementary tables). The degradation of phospholipids contributes to the rapid regeneration of ortho-phosphate, a process important in the oligotrophic central Atlantic Ocean, allowing for an efficient utilization of phosphorus in the photic layer (Vidal et al., 2003). As expected, the composition of lipids in the deep ocean indicated a higher degradation state, as shown by higher LI values than in the surface and DCM samples. However, the relatively low LI values calculated for deep waters (average 0.37 ) implied that a considerable fraction of the lipids was only little degraded and may partially originate from deep ocean particle-attached bacteria. Wax esters, which may be zooplankton derived, preferentially survived downward transport probably due to the fast sinking rate of particles (fecal pellets).

The qualitative changes in lipid composition in deep waters in comparison to the upper water column were consistent with the reactive nature of each lipid class. The overall efficiency of lipid carbon preservation at depths, however, seems to be different in the regions of the East Atlantic Ocean. There is a wide variety of possible reasons for these differences: origin of the particulate lipids, sinking velocity of the particles, photochemical degradation in the surface layer and microbial transformation within the water column.

\section{Summary and conclusions}

This study provided the unique opportunity to assess the variability of a wide range of lipid classes in different water masses along a north-south transect in the East Atlantic Ocean $\left(49^{\circ} \mathrm{N}-26^{\circ} \mathrm{S}\right)$. The ecological provinces along the transect determined the lipid concentrations and compositions. The low lipid concentrations compared to other open-ocean studies were likely related to the trophic status of the oligotrophic conditions of the subtropical and tropical East Atlantic Ocean. In the surface layer microphytoplankton was the main determinant for the lipid production whereas in the DCM layer smaller cells were the more important ones. Lipids originating from zooplankton were less important for the lipid budget. The low nutrient concentrations induced lipid synthesis and a phosphorussaving change from the production of phospholipids to glycolipids. The depth-related decrease of lipid classes revealed that, although reduced with depth, lipids are relatively stable compared to other biomolecules as concluded from the increased contribution of lipids to the POC pool at depth. Lipid classes including hydrocarbons and glycolipids were the most stable lipid compounds in the deep ocean. The low bacterial activity on lipids was supported by the low values of the LI index. In contrast, the proportion of phospholipids decreased with depth indicating their importance for phosphorus cycling in the upper oligotrophic ocean. Our long-distance study through the Atlantic Ocean demonstrated the high variety of possible mechanism determining and regulating lipid biosynthesis and degradation. Lipids with an average contribution of about $15 \%$ to POC belong to the main components of POC, being definitely chemically characterized and they are also precursors of the dissolved lipids. The transition from the particulate to the dissolved form and the processes involved are only little studied but are of major importance for the carbon cycling. For further insights into the lipid biogeochemistry more high 
resolution molecular analysis is necessary in combination with a very detailed picture of the ecosystem.

\section{Acknowledgments}

B. Taylor is greatly acknowledged for phytoplankton pigment data analysis. We thank the crew of the R/V Polarstern for their professional help and support. This work was partially funded by the German Research Foundation (DFG; KO 2164/8) and by the Croatian Ministry of Science, Education and Sports, Project no. 098-0982934-2717. A. Bracher received funding from the Helmholtz Impulse Fond (HGF Young Investigators Group Phytooptics). We thank Dr. Daniel Lyons and R. Alheit for the English editing.The authors gratefully acknowledge Dr. Ruth Flerus for helpful assistance during sample collection.

\section{Appendix A. Supplementary material}

Supplementary data associated with this article can be found in the online version at http://dx.doi.org/10.1016/j.dsr.2014.04.005.

\section{References}

Andersson, M.X., Stridh, M.H., Larsson, K.E., Liljenberg, C., Sandelius, A.S., 2003. Phosphate-deficient oat replaces a major portion of the plasma membrane phospholipids with the galactolipid digalactosyldiacylglycerol. FEBS Lett. 537, $128-132$.

Barlow, R.G., Cummings, D.G., Gibb, S.W., 1997. Improved resolution of mono- and divinyl chlorophylls $\mathrm{a}$ and $\mathrm{b}$ and zeaxanthin and lutein in phytoplankton extracts using reverse phase C-8 HPLC. Mar. Ecol. Prog. Ser. 161, 303-307.

Benning, C., Huang, Z.H., Gage, D.A., 1995. Accumulation of a novel glycolipid and a betaine lipid in the cells of Rhodobacter sphaeroides. Arc. Biochem. Biophys. 317, 103-111.

Bligh, E.G., Dyer, W.J., 1959. A rapid method of total lipid extraction and purification. Can. J. Biochem. Physiol. 37, 911-917.

Bourguet, N., Goutx, M., Ghiglione, J.F., Pujo-Pay, M., Mevel, G., Momzikoff, A. Mousseau, L., Guigue, C., Garcia, N., Raimbault, P., Pete, R., Oriol, L., Lefevre, D. 2009. Lipid biomarkers and bacterial lipase activities as indicators of organic matter and bacterial dynamics in contrasted regimes at the DYFAMED site, NW Mediterranean. Deep-Sea Res. II 56, 1454-1469.

Christodoulou, S., Marty, J.C., Miquel, J.C., Volkman, J.K., Rontani, J.F., 2009. Use of lipids and their degradation products as biomarkers for carbon cycling in the northwestern Mediterranean Sea. Mar. Chem. 113, 25-40.

Derieux, S., Fillaux, J., Saliot, A., 1998. Lipid class and fatty acid distributions in particulate and dissolved fractions in the North Adriatic Sea. Org. Geochem. 29, 1609-1621.

Ducklow, H.W., Harris, R., 1993. Introduction to the JGOFS North Atlantic Bloom Study. Deep-Sea Res. II 40, 1-8.

Ducklow, H.W., 2003. Biogeochemical provinces: toward a JGOFS synthesis. In: Fasham, M. (Ed.), Ocean Biogeochemistry. Springer, New York, pp. 3-17.

Field, C.B., Behrenfeld, M.J., Randerson, J.T., Falkowski, P.G., 1998. Primary production of the biosphere: integrating terrestrial and oceanic components. Science $281,237-240$.

Flerus, R., Lechtenfeld, O.J., Koch, B.P., McCallister, S.L., Schmitt-Kopplin, P., Benner, R. Kaiser, K., Kattner, G., 2012. A molecular perspective on the ageing of marine dissolved organic matter. Biogeosciences 9, 1935-1955.

Frka, S., Gašparović, B., Marić, D., Godrijan, J., Djakovac, T., Vojvodić, V., Dautović, J., Kozarac, Z., 2011. Phytoplankton driven distribution of dissolved and particulate lipids in a semi-enclosed temperate sea (Mediterranean): Spring to summer situation. Estuar. Coast. Shelf Sci. 93, 290-304.

Gašparović, B., Godrijan, J., Frka, S., Tomažić, I., Penezić, A., Marić, D., Djakovac, T., Ivančić, I., Paliaga, P., Lyons, D., Precali, R., Tepić, N., 2013. Adaptation of marine plankton to environmental stress by glycolipid accumulation. Mar. Environ. Res. 92, 120-132.

Gérin, C., Goutx, M., 1994. Iatroscan-measured particulate and dissolved lipids in the Almeria-Oran frontal system (Almofront-1, May 1991). J. Mar. Syst. 5, 343-360.

Gómez, F., Gorsky, G., Striby, L., Vargas, J.M., Gonzalez, N., Picheral, M., GarcíaLafuente, J., Varela, M., Goutx, M., 2001. Small-scale temporal variations in biogeochemical features in the Strait of Gibraltar, Mediterranean side-the role of NACW and the interface oscillation. J. Mar. Syst. 30, 207-220.

Goutx, M., Gérin, C., Bertrand, J.C., 1990. An application of latroscan thin-layer chromatography with flame ionization detection-lipid classes of microorganisms as biomarkers in the marine environment. Org. Geochem. 16, 1231-1237.

Goutx, M., Acquaviva, M., Gérin, C., 1993. Iatroscan-Measured Phospholipids from Marine Microalgae, Bacteria and Suspended particles. Inform-International
News on Fats, Oils and Related Materials. 4. American Oil Chemists Society Publishers, Urbana, IL, pp. 516-517.

Goutx, M., Guigue, C., Striby, L., 2003. Triacylglycerol biodegradation experiment in marine environmental conditions, definition of a new lipolysis index. Org. Geochem. 34, 1465-1473.

Guschina, I.A., Harwood, J.L., 2009. Algal lipids and effect of the environment on their biochemistry. In: Arts, M.T., Brett, M.T., Kainz, M.J. (Eds.), Lipids in Aquatic Ecosystems. Springer, pp. 1-24.

Hama, T., 1999. Fatty acid composition of particulate matter and photosynthetic products in subarctic and subtropical Pacific. J. Plankton Res. 21, 1355-1372.

Härtel, H., Dormann, P., Benning, C., 2000. DGD1-independent biosynthesis of extraplastidic galactolipids after phosphate deprivation in Arabidopsis. Proc. Natl. Acad. Sci. 97, 10649-10654.

Harvey, H.R., Tuttle, J.H., Bel, J., 1995. Kinetics of phytoplankton decay during simulated sedimentation: changes in biochemical composition and microbial activity under oxic and anoxic conditions. Geochim. Cosmochim. Acta 59, 367-3377.

Herndl, G.J., Reinthaler, T., Teira, E., van Aken, H., Veth, C., Pernthaler, A., Pernthaler, J., 2005. Contribution of Archaea to total prokaryotic production in the deep Atlantic Ocean. Appl. Environ. Microbiol. 71, 2303-2309.

Hirata, T., Hardman-Mountford, N.J., Brewin, R.J.W., Aiken, J., Barlow, R., Suzuki, K. Isada, T., Howell, E., Hashioka, T., Noguchi-Aita, M., Yamanaka, Y., 2011. Synoptic relationships between surface Chlorophyll-a and diagnostic pigments specific to phytoplankton functional types. Biogeosciences 8, 311-327.

Hoffmann, L.J., Peeken, I., Lochte, K., Assmy, P., Veldhuis, M., 2006. Different reactions of Southern Ocean phytoplankton size classes to iron fertilization. Limnol. Oceanogr. 51, 1217-1229.

Hudson, E.D., Helleur, R.J., Parrish, C.C., 2001. Thin-layer chromatography-pyrolysisgas chromatography-mass spectrometry: a multidimensional approach to marine lipid class and molecular species analysis. J. Chromatogr. Sci. 39, 146-152.

Hwang, J., Druffel, E.R.M., 2003. Lipid-like material as the source of the uncharacterized organic carbon in the ocean? Science 299, 881-884.

Irwin, A.J., Finkel, Z.V., Schofield, O.M.E., Falkowski, P.G., 2006. Scaling-up from nutrient physiology to the size-structure of phytoplankton communities J. Plankton Res. 28, 459-471.

Karayanni, H., Christaki, U., van Wambeke, G., Denis, M., Moutin, T., 2005. Influence of ciliated protozoa and heterotrophic nanoflagellates on the fate of primary production in the northeast Atlantic Ocean. J Geophys. Res. 110 (C07S15), 1-12.

Kattner, G., Hagen, W., 2009. Lipids in marine copepods: latitudinal characteristics and perspective to global warming. In: Arts, M.T., Brett, M.T., Kainz, M.J. (Eds.) Lipids in Aquatic Ecosystems. Springer, pp. 257-280.

Khozin-Goldberg, I., Shrestha, P., Cohen, Z., 2005. Mobilization of arachidonyl moieties from triacylglycerols into chloroplastic lipids following recovery from nitrogen starvation of the microalga Parietochloris incise. Biochim. Biophys. Acta $1738,63-71$.

Koch, B.P., Kattner, G., 2012. Sources and rapid biogeochemical transformation of dissolved organic matter in the Atlantic Surface Ocean. Biogeosciences 9 2597-2602.

Lee, R.F., Hagen, W., Kattner, G., 2006. Lipid storage in marine zooplankton. Mar Ecol. Prog. Ser. 307, 273-306.

Loh, A.N., Canuel, E.A., Bauer, J.E., 2008. Potential source and diagenetic signatures of oceanic dissolved and particulate organic matter as distinguished by lipid biomarker distributions. Mar. Chem. 112, 189-202.

Longhurst, A., 2007. Ecological Geography of the Sea, 2nd ed. Academic Press, Amsterdam, pp. 131-273.

Martin, J.H., Fitzwater, S.E., 1988. Iron deficiency limits phytoplankton growth in the north-east Pacific subarctic. Nature 331, 341-343.

Neogi, S.B. Koch, Schmitt-Kopplin, B.P., Pohl, P., Kattner, C., Yamasaki, G., Lara, R.J., S. 2011. Biogeochemical controls on the bacterial population in the eastern Atlantic Ocean. Biogeosciences 8, 3747-3759.

Parrish, C.C., 1987. Time series of particulate and dissolved lipid classes during spring phytoplankton blooms in Bedford Basin, a marine inlet. Mar. Ecol. Prog. Ser. 35, 129-139.

Parrish, C.C., Wangersky, P.J., 1987. Particulate and dissolved lipid classes in cultures of Phaeodactylum tricornutum grown in cage culture turbidostats with a range of nitrogen supply rates. Mar. Ecol. Prog. Ser. 35, 119-128.

Parrish, C.C., 1988. Dissolved and particulate marine lipid classes, a review. Mar Chem. 23, 17-40.

Parrish, C.C., Wangersky, P.J., Delmas, R.P., Ackman, R.G., 1988. Iatroscan-measured profiles of dissolved and particulate marine lipid classes over the Scotian slope and in Bedford Basin. Mar. Chem. 23, 1-15.

Penezić, A., Gašparović, B., Burić, Z., Frka, S., 2010. Distribution of marine lipid classes in salty Rogoznica Lake (Croatia). Estuar. Coast. Shelf Sci. 86, 625-636.

Pérez, V., Fernández, E., Marañón, E., Morán, X.A.G., Zubkov, M.V., 2006. Vertical distribution of phytoplankton biomass, production and growth in the Atlantic subtropical gyres. Deep-Sea Res. I 53, 1616-1634.

Porter, K.G., Feig, Y.S., 1980. The use of DAPI for identifying and counting aquatic microflora. Limnol. Oceanogr. 25, 943-948.

Sarthou, G., Baker, A.R., Blain, S., Achterberg, E.P., Boye, M., Bowie, A.R., Croot, P., Laan, P., de Baar, H.J.W., Jickells, T.D., Worsfold, P.J., 2003. Atmospheric iron deposition and sea-surface dissolved iron concentrations in the eastern Atlantic Ocean. Deep-Sea Res. I 50, 1339-1352.

Sathyendranath, S., Longhurst, A.R., Caverhill, C.M., Platt, T., 1995. Regionally and seasonally differentiated primary production in the North Atlantic. Deep-Sea Res. I 42, 1773-1802. 
Schouten, S., Middelburg, J.J., Hopmans, E.C., Sinninghe Damsté, J.S., 2010. Fossilization and degradation of intact polar lipids in deep subsurface sediments: a theoretical approach. Geochim. Cosmochim. Acta 74, 3806-3814.

Shifrin, N.S., Chishilm, S.W., 1981. Phytoplankton lipids: Interspecific differences and effects of nitrate, silicate and light-dark cycles. J. Phycol. 17, 374-384.

Smith, R.E.H., Gosselin, M., Kattner, G., Legendre, L., Pesant, S., 1997. Biosynthesis of macromolecular and lipid classes by phytoplankton in the Northeast Water Polynya. Mar. Ecol. Prog. Ser. 147, 231-242.

Taylor, B.B., Torrecilla, E., Bernhardt, A., Taylor, M.H., Peeken, I., Rottgers, R., Piera, J., Bracher, A., 2011. Bio-optical provinces in the eastern Atlantic Ocean and their biogeographical relevance. Biogeosciences 8, 3609-3629.

Taylor, B.B., Taylor, M.H., Dinter, T., Bracher, A., 2013. Estimation of relative phycoerythrin concentrations from hyperspectral underwater radiance measurements-a statistical approach. J. Geophys. Res.-Oceans 118, 2948-2960.

Tegelaar, E.W., De Leeuw, J.W., Derenne, S., Largeau, C., 1989. A reappraisal of kerogen formation. Geochim. Cosmochim. Acta 53, 3103-3107.

Uitz, J., Claustre, H., Morel, A., Hooker, S.B., 2006. Vertical distribution of phytoplankton communities in open ocean: an assessment based on surface chlorophyll. J. Geophys. Res. 111 (C08005), 1-23.

Uitz, J., Claustre, H., Gentili, B., Stramski, D., 2010. Phytoplankton class-specific primary production in the world's oceans: Seasonal and interannual variability from satellite observations. Global Biogeochem. Cycles 24, 1-19.

Van Mooy, B.A.S., Rocap, G., Fredricks, H.F., Evans, C.T., Devol, A.H., 2006. Sulfolipids dramatically decrease phosphorus demand by picocyanobacteria in oligotrophic marine environments. Proc. Natl. Acad. Sci. 103, 8607-8612.
Van Mooy, B.A.S., Fredricks, H.F., 2010. Bacterial and eukaryotic intact polar lipids in the eastern subtropical South Pacific: water-column distribution, planktonic sources, and fatty acid composition. Geochim. Cosmochim. Acta 74, 6499-6516. Van Wambeke, F., Goutx, M., Striby, L., Sempéré, R., Vidussi, F., 2001. Bacterial dynamics during the transition from spring bloom to oligotrophy in the northwestern Mediterranean Sea: relationships with particulate detritus and dissolved organic matter. Mar. Ecol. Prog. Ser. 212, 89-105.

Vidal, M., Duarte, C.M., Agustí, S., Gasol, J.M., Vaqué, D., 2003. Alkaline phosphatase activities in the central Atlantic Ocean indicate large areas with phosphorus deficiency. Mar. Ecol. Prog. Ser. 262, 43-53.

Wakeham, S.G., Lee, C., Farrington, J.W., Gagosian, R.B., 1984. Biogeochemistry of particulate organic matter in the oceans, results from sediment trap experiments. Deep-Sea Res. 31, 509-528.

Wakeham, S.G., Hedges, J.I., Lee, C., Peterson, M.L., Hernest, P.J., 1997. Compositions and transport of lipid biomarkers through the water column and surficial sediments of the equatorial Pacific Ocean. Deep-Sea Res. II 44, 2131-2162.

Yoshimura, K., Ogawa, T., Hama, T., 2009. Degradation and dissolution properties of photosynthetically-produced phytoplankton lipid materials in early diagenesis. Mar. Chem. 114, 11-18.

Zhukova, N.V., Aizdaicher, N.A., 2001. Lipid and fatty acid composition during vegetative and resting stages of the marine diatom Chaetoceros salsugineus. Bot. Mar. 44, 287-293. 